\title{
KAJIAN SEBARAN KADMIUM DALAM SAYURAN DAN TANAH DI BANTARAN SUNGAI CIKARANG BEKASI LAUT (CBL)
}

\section{The Study of Cadmium Distribution in Vegetable and Soil Located in River Bank of Cikarang Bekasi Laut (CBL) River}

\section{Alfandi'1), Salaudin Djalal Tandjung'), Bostang Radjagukguk ${ }^{3)}$ dan Narsito4)}

\author{
${ }^{1}$ Program Studi Ilmu Lingkungan Universitas Gadjah Mada \\ 2 Jurusan Biologi, MIPA Universitas Gadjah Mada \\ 3 Fakultas Pertanian Universitas Gadjah Mada \\ 4 Jurusan Kimia, MIPA, Universitas Gadjah Mada
}

\begin{abstract}
Contamination of contaminants in river are more due to human activities (antropogenic), such as the disposal of industrial waste and domestic waste. One type of inorganic pollutants that is toxic to living organism including human is cadmium $(C d)$. The movement of $C d$ in river water into the soil along the river is naturally and by human activity. The objectives of this study was to examine the distribution of $C d$ in soil on the river banks of the Cikarang Bekasi Laut (CBL) river, in Bekasi West Java, based on the distance from the pollutant sources during rainy and dry season (spatially and temporally). This study used a survey method in sampling plants, water and soil. Sampling was conducted at 10 sites and 10 observation times (dry and rainy season). The analyses of $\mathrm{Cd}$ content were conducted on plant, water and soil samples. In addition, $\mathrm{pH}$ was also measured in soil and water samples. Vegetable samples were collected from the field were kale, spinach and caisin. Statistical analyses comparized of analyses of variance (F test), comparatine analyses of the mean and correlation analyses. The results showed that the contents of $C d$ in the soil samples that close to the surface of the river water were higher than those of other soil samples. This was caused by the movement of Cd from the river water naturally due to changes in water level or river discharge fluctuation, as a consequence of changes in dry and rainy seasons. At sites further from the river (on land of cultivation), the presence of $C d$ in soil was mainly due to the use of river water for irrigation. Watering plant was mostly done during the dry season, at which the concentration of $C d$ in river water was relatively higher. The content of Cd in plant tissue (Spinach, kale and caisin) had a positive correlation with the content of Cd in the soil. The average content of Cd from the three plants were spinach > kale > caisin, consecutively.
\end{abstract}

Keywords: antropogenic, cadmium (Cd), Cd uptake, pollution, riverbanks

\section{PENDAHULUAN}

Air sungai yang mengalir di daerah perkotaan (daerah padat pemukiman dan industri), memiliki kualitas yang sangat rendah akibat pembuangan limbah domestik dan industri. Kedua sumber tersebut memberikan kontribusi utama terhadap pencemaran di badan air permukaan. Salah satu jenis limbah anorganik yang dihasilkan oleh kegiatan industri dan bersifat sangat berbahaya bagi kesehatan manusia adalah logam berat. Logam berat dapat secara langsung bersifat toksik bagi tanaman, atau menjadi sangat berbahaya bagi hewan dan manusia yang mengkonsumsinya setelah logam tersebut memasuki rantai makanan (Vlamis et al., 1985). Beberapa logam berat yang berpotensi menimbulkan risiko toksik (hazardous) adalah $\mathrm{Hg}, \mathrm{Cd}, \mathrm{Cr}$ dan $\mathrm{Pb}$ yang menjadi perhatian utama sejak tiga dekade yang lalu (Sommers, 1980 dalam Vlamis et al., 1985). Diantara logam berat tersebut logam Cd akan menjadi fokus dalam penelitian ini, mengingat hulu Sungai Cikarang Bekasi Laut (CBL) yaitu Sungai Cikarang dan anak Sungai Bekasi terdapat banyak jenis industri yang berpotensi menghasilkan limbah $\mathrm{Cd}$. Hasil penelitian yang dilakukan oleh Fachrul et al. (2004), menunjukkan bahwa muara Sungai CBL telah mengalami pencemaran berat oleh limbah industri dan domestik. Kadmium sangat membahayakan kesehatan manusia karena pengaruh racun akut dari unsur tersebut sangat buruk. Kasus keracunan $\mathrm{Cd}$ yang banyak dijadikan referensi adalah yang terjadi di Jepang yang biasa disebut dengan Itai-itai disease.

Logam berat yang ada di dalam air sungai sifatnya tidak dapat didegradasi, sehingga logam ini akan larut dalam air atau mengendap di dalam sedimen dalam berbagai macam bentuk kimia (spesiasi). Apabila proses pengendapan terjadi secara terus-menerus, maka biota di kawasan (ekosistem) perairan tersebut akan mengalami gangguan. Menurut Murray et al. (2004), bantaran sungai pada kawasan industri dari suatu daerah aliran sungai mempunyai konsentrasi logam berat yang sangat tinggi dibandingkan kawasan permukiman maupun wilayah perdesaan. Menurut Robert (1999) bahwa sumbangan limbah domestik di wilayah perkotaan terhadap logam $\mathrm{Cd}$ dalam perairan adalah sebesar $11 \%$ dari total kandungan dalam air sungai dan sisanya $(89 \%)$ tentunya berasal dari industri. Sungai yang mengandung logam Cd berlebihan 
dapat mencemari tanah sekitarnya, baik melalui irigasi maupun pembuangan sedimen yang dikeruk atau akibat banjir. Hasil penelitian di Jepang, menunjukkan bahwa sungai dapat mengangkut $\mathrm{Cd}$ dengan jarak yang cukup jauh yaitu hingga $50 \mathrm{~km}$ dari sumber (Tsuchiya, 1978 dalam World Health Organization, 1992).

Di bantaran Sungai CBL termasuk di Kecamatan Babelan, Kabupaten Bekasi para petani menggunakan bantaran sungai sebagai lahan pertanian untuk budidaya, khususnya tanaman sayuran. Sumber air irigasi berasal dari air Sungai CBL, sehingga apabila air sungai mengandung polutan logam berat, maka logam berat tersebut ikut dan akan mengendap di lahan pertanian, dan selanjutnya diperkirakan akan masuk ke jaringan tanaman melalui mekanisme serapan (absorption). Oleh karena itu, usahatani tanaman pangan dan sayuran di bantaran Sungai CBL memiliki risiko adanya kandungan logam berat yang tinggi. Para petani tentunya tidak menyadari akan hal tersebut, karena bagi petani yang lebih penting adalah tingkat pertumbuhan dan produksi yang tinggi. Serapan $\mathrm{Cd}$ yang tinggi belum tentu menunjukkan adanya gejala toksisitas (khlorosis) pada tanaman (sayuran).

Kandungan logam berat dalam tanah secara alamiah rata-rata $0.06 \mathrm{mg} \mathrm{kg}^{-1}$ (Peterson dan Alloway, 1979 dalam Darmono, 1995). Hasil penelitian Chaudri et al. (2001), menunjukkan adanya hubungan yang nyata dan bersifat linier antara $\mathrm{Cd}$ terlarut dengan $\mathrm{Cd}$ total dalam tanah, demikian pula antara $\mathrm{Cd}$ total dalam tanah dengan $\mathrm{Cd}$ yang terserap oleh tanaman. Namun demikian hubungan antara $\mathrm{Cd}$ terlarut jauh lebih linier dengan $\mathrm{Cd}$ dalam tanaman dibandingkan dengan $\mathrm{Cd}$ total dalam tanah. Korelasi antara
Cd total dalam tanah dan $\mathrm{Cd}$ dalam biji gandum antara tahun 1994, 1996 dan 1999 sangat nyata, dengan nilai koefisien korelasi (r) berturut-turut adalah 0.90; 0.87; dan 0.85 .

\section{BAHAN DAN METODE}

Bahan yang digunakan meliputi Peta Rupa Bumi Skala 1:25.000 di wilayah Sungai CBL, yang terdiri dari 11 lembar, sampel tanaman (bayam, kangkung dan caisin) dari lahan petani, bahan-bahan untuk analisis kimia tanah, air dan tanaman. Alat yang digunakan meliputi GPS tipe Garmin tipe 60CSx, bor belgi, alat pengambilan sampel tanah dan air, serta alat pengukuran debit sungai. Pengolahan peta RBI menjadi peta tematik dilakukan di laboratorium GIS Fakultas Geografi UGM Yogyakarta.

Penelitian dilakukan dengan metode survey yaitu dalam pengambilan sampel tanaman, sampel tanah dan air sungai pada titik-titk lokasi dan waktu yang telah ditetapkan, dapat dilihat pada Tabel 1. Penetapan titik-titik lokasi dilakukan dengan teknik Purposive Sampling, yaitu penentuan titik sampling berdasarkan pertimbangan : a) adanya konsentrasi pemanfaatan lahan oleh petani di bantaran sungai untuk budidaya tanaman sayuran, b) jarak titik lokasi dengan percabangan anak sungai, dan c) jarak antar titik-titik lokasi yang satu dengan yang lainnya. Selanjutnya penetapan waktu pengambilan sampel dilakukan pada beberapa waktu di musim penghujan dan kemarau. Berdasar pertimbangan tersebut telah ditetapkan 10 titik lokasi (Gambar 1) pengambilan sampel air, tanah dan tanaman dan 10 titik waktu pengamatan.

Tabel 1. Lokasi dan waktu pengambilan sampel tanaman, tanah dan air

\begin{tabular}{|c|c|c|c|c|c|c|}
\hline \multirow{2}{*}{ No. } & \multirow{2}{*}{$\begin{array}{c}\text { Kode } \\
\text { Lokasi }\end{array}$} & \multicolumn{2}{|c|}{ Koordinat UTM *) } & \multicolumn{3}{|c|}{ Waktu Pengambilan Sampel } \\
\hline & & L. Selatan & B. Timur & kode & Tanggal & Musim \\
\hline 1 & L-1 & $9,309,456.55$ & $735,837.52$ & $\mathrm{~T} 1$ & 19-03-2007 & Penghujan \\
\hline 2 & L-2 & $9,310,572.18$ & $733,281.95$ & $\mathrm{~T} 2$ & $26-03-2007$ & Penghujan \\
\hline 3 & L-3 & $9,311,467.28$ & $731,193.39$ & $\mathrm{~T} 3$ & 01-06-2007 & Kemarau \\
\hline 4 & L-4 & $9,313,802.32$ & $730,337.21$ & $\mathrm{~T} 4$ & 08-06-2007 & Kemarau \\
\hline 5 & $\mathrm{~L}-5$ & $9,317,681.07$ & $729,065.92$ & $\mathrm{~T} 5$ & 21-08-2007 & Kemarau \\
\hline 6 & L-6 & $9,321,507.94$ & $728,365.40$ & T6 & $28-08-2007$ & Kemarau \\
\hline 7 & $\mathrm{~L}-7$ & $9,323,155.44$ & $727,522.20$ & $\mathrm{~T} 7$ & $13-02-2008$ & Penghujan \\
\hline 8 & L-8 & $9,326,139.09$ & $725,861.73$ & $\mathrm{~T} 8$ & $20-02-2008$ & Penghujan \\
\hline 9 & L-9 & $9,314,801.19$ & $729,766.43$ & T9 & 05-07-2008 & Kemarau \\
\hline 10 & L-10 & $9,322,130.61$ & $727,703.81$ & $\mathrm{~T} 10$ & $12-07-2008$ & Kemarau \\
\hline
\end{tabular}

Ket : *) Jarak lurus lokasi dari titik percobaan lapangan

Penetapan koordinat geografis/UTM menggunakan alat GPS Garmin tipe 60CSx. 


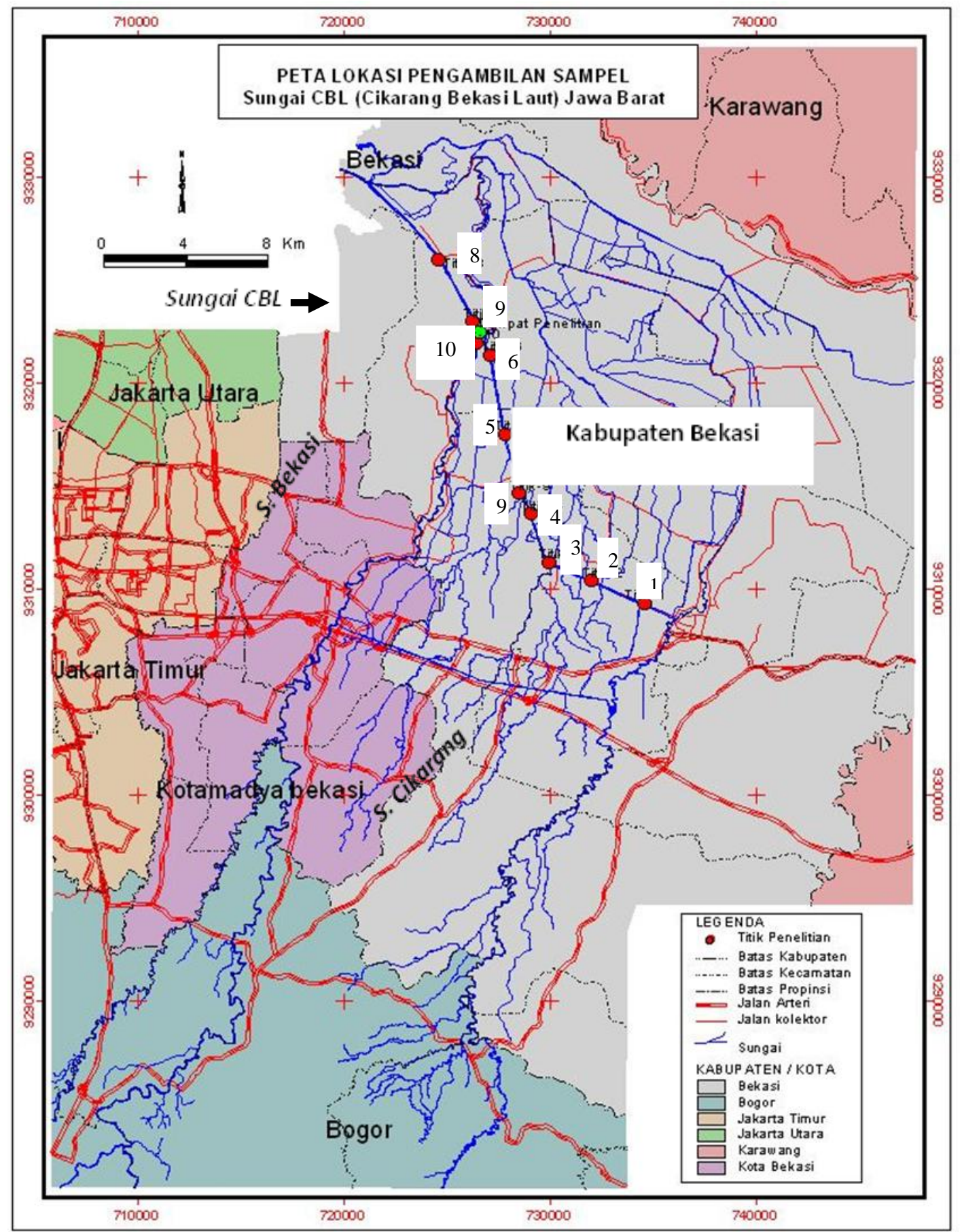

Gambar 1. Peta lokasi pengambilan 10 titik sampel di Kabupaten Bekasi

\section{Pengambilan Sampel dan Analisis}

Pengambilan sampel air sungai dimaksudkan untuk analisis konsentrasi $\mathrm{Cd}$ dan pengukuran $\mathrm{pH}$ air pada setiap titik lokasi dan 10 waktu pengamatan. Pengambilan sampel dilakukan dengan menggunakan botol water sampler yang bervolume $250 \mathrm{ml}$. Pengambilan sampel tanah dilakukan secara komposit pada masing-masing 10 titik lokasi (L-1 sampai dengan L-10). Setiap titik lokasi diambil 2 titik sampel komposit secara lateral (melintang), yaitu titik A (berjarak $3 \mathrm{~m}$ dari rata-rata tinggi muka air) dan titik $\mathrm{B}$ (berjarak $10 \mathrm{~m}$ dari rata-rata tinggi muka air). Pengambilan sampel tanah hanya diambil sebanyak 5 waktu pengamatan, yaitu T1, T3, T6, T8 dan T10 karena jarak waktu antara T1 dan T2 hanya 1 minggu, demikian pula antara T3-T4, T5T6, T7-T8 serta T9-T10 (Tabel 1). Pertimbangannya adalah konsentrasi $\mathrm{Cd}$ dan $\mathrm{pH}$ di tanah dalam waktu 1 minggu relatif lebih konstan dibanding di dalam air sungai.

Untuk sampel tanaman diambil dari lahan petani meliputi tanaman kangkung, bayam dan caisin. Umur ketiga jenis tanaman untuk sampel berkisar antara umur 2527 hari setelah tanam. Setiap jenis tanaman dianalisis kandungan $\mathrm{Cd}$ pada bagian akar dan tajuk.

Prosedur dalam analisis parameter kimia terhadap sampel tanah, air dan tanaman didasarkan kepada Petunjuk Teknis Analisis Kimia Tanah, Tanaman Air dan Pupuk oleh Balai Penelitian Tanah (2005). Unsur logam Cd dalam tanah dan tanaman diekstrak dengan cara pengabuan basah 
menggunakan campuran asam pekat $\mathrm{HNO}_{3}$ dan $\mathrm{HClO}_{4}$. Adapun bahan/pereaksi yang digunakan meliputi $\mathrm{HNO}_{3}$ pekat $(65 \%)$ p.a., $\mathrm{HClO}_{4}$ pekat $(60 \%)$ p.a., standar 0 (larutan $\mathrm{HClO}_{4} 10 \%$ ), Standar pokok $1.000 \mathrm{ppm} \mathrm{Cd}$ (titrisol). Kadar logam Cd yang telah diekstrak selanjutnya diukur menggunakan AAS (atomic absorption spectrophotometry).

Uji keragaman dilakunan untuk melihat pengaruh lokasi dan waktu pengambilan sampel. Dalam analisis ini variabel bebas (independent variable) adalah Lokasi (L-1 sampai dengan L-8) dan Waktu (sesuai dengan waktu pengambilan sampel). Adapun Model Linier dari Analisis keragaman tersebut adalah sebagai berikut :

$\mathrm{Yij}=\mu \ldots+\mathrm{Li}+\mathrm{Wj}+\varepsilon \mathrm{ij}$, dimana $\mathrm{Li}$ adalah pengaruh aditif lokasi ke-i dan $\mathrm{Wj}$ adalah pengaruh aditif waktu ke-j. Untuk mengevaluasi keterkaitan atau hubungan antara berbagai variabel yang diamati maka dilakukan uji korelasi pearson.

\section{HASIL DAN PEMBAHASAN}

\section{Wilayah Studi}

Wilayah studi dalam penelitian ini terdapat di Sungai CBL, Kabupaten Bekasi, Provinsi Jawa Barat. Panjang Sungai CBL sampai dengan muara di Laut Jawa adalah $29.2 \mathrm{~km}$. Sungai CBL adalah suatu saluran buatan (saluran pembuangan atau "sudetan") dari Sungai Cikarang dan Sungai Bekasi yang melewati daerah Kabupaten Bekasi. Hulu Sungai CBL adalah Sungai Cikarang dan bermuara di Teluk Jakarta. Jenis tanah di bantaran Sungai CBL didominasi jenis tanah Latosol Merah Kekuningan. Sungai CBL melewati beberapa kecamatan, diantaranya kecamatan Cibitung, Tambun Utara, Tambun Selatan, Sukawangi, Babelan, dan kecamatan Muaragembong. Keenam kecamatan tersebut berada di wilayah administrasi Kabupaten Bekasi. Untuk melihat gambaran dari industri yang berpotensi menghasilkan limbah $\mathrm{Cd}$ di wilayah kabupaten Bekasi dapat dilihat pada Tabel 2.

Tabel 2. Jenis industri besar dan menengah di Kabupaten Bekasi yang berpotensi menghasilkan limbah mengandung $\mathrm{Cd}$

\begin{tabular}{clcc}
\hline No & \multicolumn{1}{c}{ Jenis Industri } & Jumlah & $\%$ \\
\hline 1. & Zat warna (cat) & 5 & 2.16 \\
2. & Elektroplating & 17 & 7.33 \\
3. & Logam/Campuran logam & 44 & 18.97 \\
4. & Tekstil & 13 & 5.60 \\
5. & Kimia & 22 & 9.48 \\
6. & Elektronika & 12 & 5.17 \\
7. & Lain-lain *) & 119 & 51.29 \\
\hline & Jumlah & 232 & 100.00 \\
\hline
\end{tabular}

*) termasuk lain-lain : industri furniture, makanan dan minuman, buah dan sayuran, dan percetakan (pengolahan data sekunder Anonim, 2007)

\section{Debit dan Konsentrasi Cd Air Sungai}

Kandungan Cd dalam air Sungai CBL pada 2 musim (Penghujan dan Kemarau) ditunjukkan pada Tabel 3.

Tabel 3. Debit dan konsentrasi Cd air sungai CBL pada 3 titik lokasi pengamatan pada 10 waktu pengukuran

\begin{tabular}{|c|c|c|c|c|c|c|c|c|}
\hline \multirow[t]{3}{*}{ No. } & \multirow{2}{*}{\multicolumn{2}{|c|}{ Waktu Pengukuran *) }} & \multicolumn{3}{|c|}{ Debit Air Sungai $\left(\mathrm{m}^{3} \mathrm{dt}^{-1}\right)$} & \multicolumn{3}{|c|}{ Cd Air Sungai $\left(\mathrm{mg} \mathrm{L}^{-1}\right)$} \\
\hline & & & \multicolumn{3}{|c|}{ Lokasi } & \multicolumn{3}{|c|}{ Lokasi } \\
\hline & Tanggal & Kode & L-1 & $\mathrm{L}-5$ & $\mathrm{~L}-7$ & L-1 & $\mathrm{L}-5$ & $\mathrm{~L}-7$ \\
\hline 1. & $19-03-2007$ & $\mathrm{~T} 1$ & 11,357 & 14,366 & 37,026 & 0.002 & 0.003 & 0.000 \\
\hline 2. & 26-03-2007 & $\mathrm{T} 2$ & 9,743 & 12,113 & 35,764 & 0.005 & 0.009 & 0.004 \\
\hline 3. & 01-06-2007 & $\mathrm{T} 3$ & 8,925 & 11,238 & 31,391 & 0.008 & 0.011 & 0.008 \\
\hline 4. & 08-06-2007 & $\mathrm{T} 4$ & 8,288 & 10,688 & 28,484 & 0.009 & 0.010 & 0.011 \\
\hline 5. & $21-08-2007$ & T5 & 12,530 & 14,708 & 33,134 & 0.012 & 0.012 & 0.011 \\
\hline 6. & $28-08-2007$ & T6 & 9,173 & 11,355 & 26,323 & 0.009 & 0.012 & 0.012 \\
\hline 7. & $13-02-2008$ & $\mathrm{~T} 7$ & 13,728 & 15,141 & 35,963 & 0.004 & 0.006 & 0.009 \\
\hline 8. & 20-02-2008 & $\mathrm{T} 8$ & 9,354 & 11,591 & 29,298 & 0.009 & 0.008 & 0.011 \\
\hline 9. & 05-07-2008 & T9 & 8,606 & 10,074 & 27,321 & 0.014 & 0.013 & 0.010 \\
\hline 10. & $12-07-2008$ & $\mathrm{~T} 10$ & 6,252 & 8,524 & 26,856 & 0.015 & 0.013 & 0.013 \\
\hline
\end{tabular}

*) Musim penghujan (T1, T2, T7, dan T8), Musim kemarau (T3, T4, T5, T6, T 9 dan T10)

Hasil analisis korelasi menunjukkan adanya hubungan yang bersifat negatif antara debit dengan konsentrasi Cd sungai pada ketiga lokasi tersebut, dengan koefisien korelasi (r) pada L-1, L-5 dan L7 berturut-turut $0.585 ;-0.654 *$; dan $-0.792 * *$. Hal ini berarti bahwa semakin besar debit air sungai, maka semakin rendah konsentrasi $\mathrm{Cd}$ dan sebaliknya semakin kecil debit air sungai maka semakin tinggi konsentrasi $\mathrm{Cd}$ dalam air. Hal ini mudah dipahami bahwa semakin besar debit air sungai maka akan terjadi pengenceran polutan, dengan asumsi bahwa jumlah polutan yang masuk ke badan air relatif konstan. Oleh karena itu pada musim kemarau konsentrasi polutan, termasuk $\mathrm{Cd}$ juga semakin tinggi. Hasil yang sama juga diperoleh dari penelitian Gundersen dan Steinnes (2001), bahwa terdapat hubungan negatif yang signifikan antara konsentrasi $\mathrm{Cd}$ dengan debit air sungai.

\section{Sebaran Cd dalam Tanah di Bantaran Sungai CBL}

Hasil analisis kandungan $\mathrm{Cd}$ tanah pada setiap lokasi sepanjang bantaran Sungai CBL ditunjukkan dalam Tabel 4. 
Tabel 4. Kadar Cd dalam tanah di bantaran sungai CBL pada titik A dan B di setiap titik lokasi dan 5 waktu pengamatan

\begin{tabular}{|c|c|c|c|c|c|c|c|c|c|c|}
\hline \multirow[t]{3}{*}{ Lokasi } & \multicolumn{10}{|c|}{ Cd Tanah di Bantaran Sungai CBL pada 5 Waktu Pengamatan $\left(\mathrm{mg} \mathrm{kg}^{-1}\right)$} \\
\hline & \multicolumn{2}{|c|}{$\mathrm{T} 1$} & \multicolumn{2}{|c|}{ T3 } & \multicolumn{2}{|c|}{ T6 } & \multicolumn{2}{|c|}{ T8 } & \multicolumn{2}{|c|}{ T10 } \\
\hline & A & B & A & B & A & B & A & B & A & B \\
\hline L-1 & 0.32 & 0.21 & 0.33 & 0.24 & 0.43 & 0.39 & 0.43 & 0.38 & 0.48 & 0.33 \\
\hline L-2 & 0.19 & 0.13 & 0.22 & 0.17 & 0.47 & 0.43 & 0.44 & 0.41 & 0.44 & 0.33 \\
\hline L-3 & 0.22 & 0.18 & 0.26 & 0.21 & 0.27 & 0.16 & 0.22 & 0.15 & 0.32 & 0.13 \\
\hline L-4 & 0.39 & 0.23 & 0.37 & 0.29 & 0.49 & 0.37 & 0.46 & 0.31 & 0.58 & 0.23 \\
\hline L-5 & 0.03 & 0.24 & 0.12 & 0.33 & 0.48 & 0.34 & 0.45 & 0.32 & 0.52 & 0.22 \\
\hline L-6 & 0.30 & 0.22 & 0.33 & 0.26 & 0.51 & 0.50 & 0.54 & 0.43 & 0.49 & 0.33 \\
\hline L-7 & 0.34 & 0.12 & 0.42 & 0.21 & 0.54 & 0.15 & 0.48 & 0.15 & 0.34 & 0.03 \\
\hline L-8 & 0.25 & 0.12 & 0.23 & 0.17 & 0.42 & 0.27 & 0.27 & 0.03 & 0.41 & 0.06 \\
\hline L-9 & 0.43 & 0.07 & 0.34 & 0.19 & 0.45 & 0.07 & 0.37 & 0.15 & 0.41 & 0.17 \\
\hline L-10 & 0.36 & 0.11 & 0.37 & 0.26 & 0.37 & 0.15 & 0.53 & 0.09 & 0.31 & 0.02 \\
\hline
\end{tabular}

Tabel 4. menunjukkan kandungan rata-rata $\mathrm{Cd}$ dalam tanah di titik A (3 m dari muka air), adalah sebesar $0.38 \mathrm{mg} \mathrm{kg}^{-1} \pm 0.115$, nilai ini lebih tinggi dibanding kandungan $\mathrm{Cd}$ di titik $\mathrm{B}$ (10 m dari muka air), yaitu ratarata $0.22 \mathrm{mg} \mathrm{kg}^{-1} \pm 0.116$. Melalui uji statistik $t$-student (Uji beda dua pasangan populasi) menunjukkan adanya perbedaan sangat signifikan antara kandungan $\mathrm{Cd}$ dalam tanah di titik A dan titik B. Fakta ini menunjukkan bahwa Cd dalam tanah yang lebih dekat ke muka air sungai lebih tinggi kandungannya dari pada di titik yang agak jauh dari muka air sungai. Air sungai melimpas ke daratan (bantaran) secara kontinyu dan berlangsung secara terus-menerus sesuai dengan fluktuasi debit sungai. Air sungai tersebut tentunya akan membawa material, baik berupa sedimen (padatan tersuspensi) maupun berupa senyawa terlarut ke bantaran sungai. Selanjutnya, material tersebut akan diendapkan dan menyebabkan terjadinya pengendapan berbagai unsur dalam tanah, termasuk logam $\mathrm{Cd}$.

Sebaliknya, keberadaan $\mathrm{Cd}$ dalam tanah yang agak jauh dari muka air sungai, yaitu pada lahan yang digunakan untuk budidaya lebih banyak dipengaruhi oleh aktivitas manusia, yaitu melalui penggunaan air sungai sebagai air irigasi atau penyiraman pada tanaman. Kenyataan ini juga diperkuat adanya hubungan positif dan signifikan antara kandungan $\mathrm{Cd}$ tanah dengan lama penggunaan lahan untuk budidaya.
Kandungan Cd dalam tanah pada pada bantaran sungai yang digunakan sebagai lahan pertanian ternyata mempunyai korelasi dengan lama penggunaan lahan, dengan koefisien korelasi (r) sebesar 0.577**. Hal ini bermakna bahwa semakin lama penggunaan lahan maka semakin tinggi kandungan Cd dalam tanah. Penggunaan air sungai sebagai air penyiraman untuk tanaman budidaya biasanya dilakukan pada saat musim kemarau. Sementara konsentrasi $\mathrm{Cd}$ dalam air sungai lebih tinggi pada musim kemarau tersebut, sehingga jumlah $\mathrm{Cd}$ yang masuk ke lahan budidaya juga semakin besar jumlahnya.

\section{Kandungan Cd dalam Sampel Tanaman}

Hasil analisis kandungan $\mathrm{Cd}$ dalam jaringan tanaman pada masing-masing lokasi di bantaran Sungai CBL ditunjukkan pada Tabel 5. Rata-rata kandungan Cd dalam jaringan dari seluruh sampel tanaman (kangkung, bayam dan caisin) adalah sebesar $0.53 \mathrm{mg} \mathrm{kg}^{-1} \pm 0.045 \mathrm{di}$ bagian akar, dan $0.32 \mathrm{mg} \mathrm{kg}^{-1} \pm 0.047$ di bagian tajuk. Untuk mengevaluasi apakah nilai tersebut tergolong rendah atau tinggi maka akan dibandingkan dengan batas maksimum yang diperkenankan menurut SNI No. 7387 untuk Cd sebesar $0.20 \mathrm{mg} \mathrm{kg}^{-1}$ berat segar. 
Tabel 5. Kadar Cd dalam jaringan tanaman sayuran bagian akar dan tajuk

\begin{tabular}{|c|c|c|c|c|c|c|c|c|c|c|c|}
\hline \multirow[b]{2}{*}{ Lokasi } & \multicolumn{10}{|c|}{ Cd Jaringan Tanaman $\left(\mathrm{mg} \mathrm{kg}^{-1} \mathrm{BK}^{*}\right)$ pada setiap Waktu Pengamatan } & \multirow{2}{*}{$\begin{array}{l}\text { LPL } \\
\text { (th) }\end{array}$} \\
\hline & \multicolumn{2}{|c|}{$\mathrm{T} 1$} & \multicolumn{2}{|c|}{$\mathrm{T} 3$} & \multicolumn{2}{|c|}{ T6 } & \multicolumn{2}{|c|}{$\mathrm{T} 8$} & \multicolumn{2}{|c|}{ T10 } & \\
\hline Bayam & Akar & Tajuk & Akar & Tajuk & Akar & Tajuk & Akar & Tajuk & Akar & Tajuk & LPL \\
\hline $\mathrm{L}-1$ & 0.63 & 0.34 & 0.63 & 0.27 & 0.66 & 0.40 & 0.80 & 0.43 & 0.75 & 0.41 & 12 \\
\hline $\mathrm{L}-2$ & 0.57 & 0.25 & 0.64 & 0.44 & 0.77 & 0.43 & 0.79 & 0.51 & 0.76 & 0.40 & 7 \\
\hline $\mathrm{L}-5$ & 0.79 & 0.62 & 0.62 & 0.34 & 0.89 & 0.48 & 0.89 & 0.60 & 0.76 & 0.51 & 14 \\
\hline L-6 & 0.53 & 0.40 & 0.62 & 0.46 & 0.92 & 0.45 & 0.89 & 0.55 & 0.89 & 0.50 & 15 \\
\hline Rerata & 0.61 & 0.40 & 0.63 & 0.39 & 0.80 & 0.44 & 0.86 & 0.52 & 0.76 & 0.44 & 12 \\
\hline kangkung & Akar & Tajuk & Akar & Tajuk & Akar & Tajuk & Akar & Tajuk & Akar & Tajuk & LPL \\
\hline L-1 & 0.51 & 0.28 & 0.45 & 0.28 & 0.54 & 0.38 & 0.54 & 0.34 & 0.45 & 0.29 & 12 \\
\hline L-2 & 0.42 & 0.25 & 0.43 & 0.26 & 0.63 & 0.42 & 0.72 & 0.42 & 0.79 & 0.49 & 7 \\
\hline L-8 & 0.46 & 0.38 & 0.56 & 0.43 & 0.36 & 0.19 & 0.35 & 0.19 & 0.36 & 0.18 & 5 \\
\hline L-9 & 0.44 & 0.28 & 0.46 & 0.29 & 0.44 & 0.25 & 0.43 & 0.25 & 0.43 & 0.29 & 4 \\
\hline L-10 & 0.56 & 0.37 & 0.46 & 0.30 & 0.46 & 0.31 & 0.45 & 0.29 & 0.45 & 0.28 & 6 \\
\hline Rerata & 0.48 & 0.34 & 0.48 & 0.34 & 0.52 & 0.32 & 0.53 & 0.32 & 0.52 & 0.32 & 12 \\
\hline Caisin & Akar & Tajuk & Akar & Tajuk & Akar & Tajuk & Akar & Tajuk & Akar & Tajuk & LPL \\
\hline L-2 & 0.32 & 0.16 & 0.23 & 0.09 & 0.34 & 0.21 & 0.34 & 0.17 & 0.18 & 0.20 & 7 \\
\hline L-3 & 0.24 & 0.12 & 0.24 & 0.10 & 0.27 & 0.11 & 0.26 & 0.10 & 0.33 & 0.18 & 9 \\
\hline $\mathrm{L}-5$ & 0.42 & 0.18 & 0.32 & 0.18 & 0.42 & 0.16 & 0.26 & 0.08 & 0.32 & 0.17 & 14 \\
\hline L-6 & 0.26 & 0.21 & 0.32 & 0.20 & 0.34 & 0.17 & 0.34 & 0.17 & 0.41 & 0.23 & 15 \\
\hline Rerata & 0.31 & 0.17 & 0.28 & 0.14 & 0.34 & 0.16 & 0.30 & 0.13 & 0.31 & 0.20 & 7 \\
\hline
\end{tabular}

Keterangan : *) Perhitungan berdasar bobot kering mutlak

LPL = Lama Penggunaan Lahan untuk Budidaya Pertanian

Rata-rata kadar air (KA) dari ketiga tanaman kangkung, bayam dan caisin berturut-turut $87.5 \% ; 91.4 \%$ dan $86.6 \%$. Melalui perhitungan konversi kandungan $\mathrm{Cd}$ ke berat segar, menunjukkan bahwa rata-rata kandungan $\mathrm{Cd}$ dalam jaringan dari ketiga jenis tanaman (secara keseluruhan) adalah sebesar $0.10 \mathrm{mg} \mathrm{kg}^{-1} \pm 0.006$ di bagian akar dan $0.04 \mathrm{mg} \mathrm{kg}^{-1} \pm 0.006$ di bagian tajuk. Nilai tersebut ternyata masih berada di bawah batas maksimum yang diperkenankan menurut SNI.
Perbandingan kandungan Cd dalam akar dan tajuk tanaman menunjukkan kondisi yang hampir sama dengan penelitian yang dilakukan oleh Salviano, Fontes dan Neves (2001) juga menunjukkan bahwa kandungan Cd akar lebih tinggi dari pada bagian atas (batang dan daun). Hasil ini juga menunjukkan bahwa Cd lebih banyak terakumulasi di bagian akar tanaman, dan selanjutnya akan di translokasi ke bagian tajuk. Berdasar hasil analisis korelasi pada ketiga jenis sayuran tersebut dapat ditunjukkan pada Gambar 2, 3 san 4.

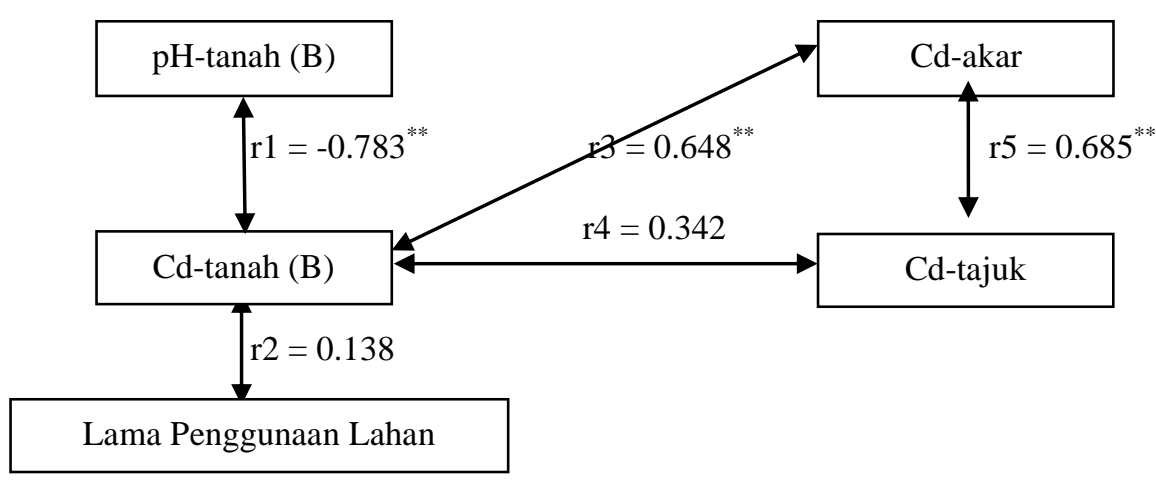

Gambar 2. Hubungan antara kadar Cd dalam tanah, Cd dalam akar dan tajuk tanaman bayam, pH tanah, dan lama penggunaan lahan 


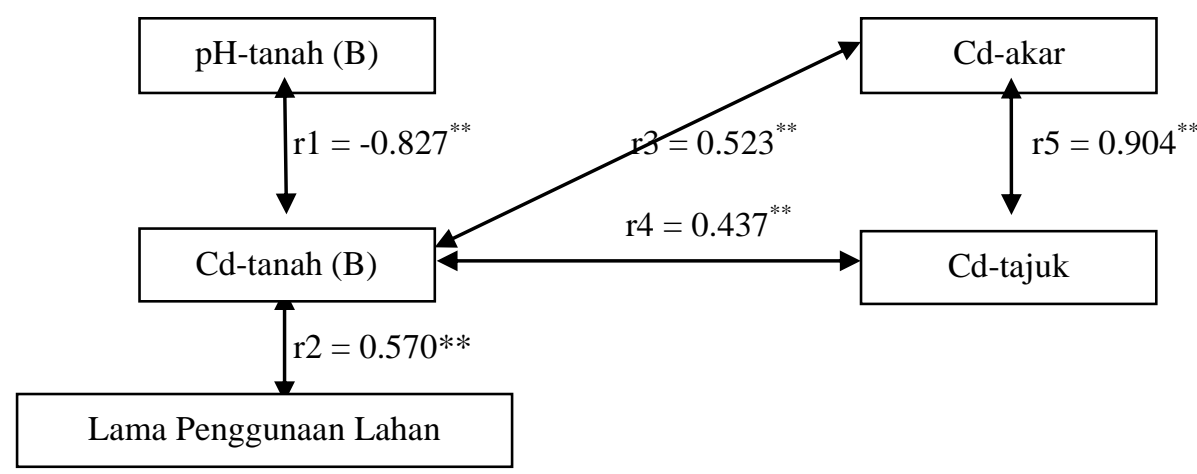

Gambar 3. Hubungan antara kadar Cd dalam tanah, Cd dalam akar dan tajuk tanaman kangkung, pH tanah, dan lama penggunaan lahan

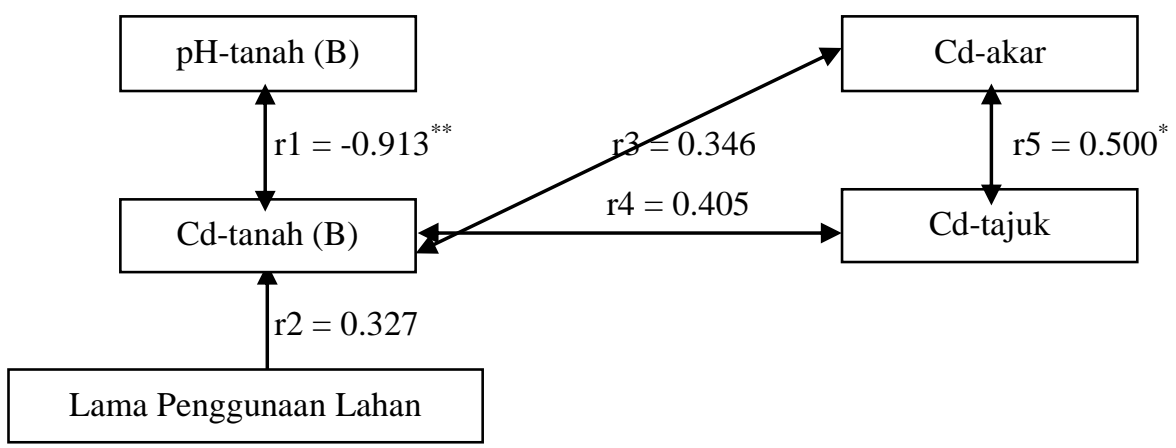

Gambar 4. Hubungan antara kadar Cd dalam tanah, Cd dalam akar dan tajuk tanaman caisin, pH tanah, dan lama penggunaan lahan

Ketiga gambar tersebut secara umum menunjukkan bahwa terdapat korelasi positif yang signifikan antara $\mathrm{Cd}$ tanah dan Cd akar serta Cd akar dan Cd tajuk. Hal ini menunjukkan bahwa kandungan $\mathrm{Cd}$ dalam jaringan tanaman sangat ditentukan oleh $\mathrm{Cd}$ dalam tanah. Fakta ini bermakna pula bahwa semakin tinggi ketersediaan $\mathrm{Cd}$ dalam tanah maka semakin tinggi serapannya oleh akar tanaman. Unsur $\mathrm{Cd}$ meskipun bukan hara esensial bagi tanaman, namun apabila dalam tanah jumlahnya cukup dan tersedia maka tanaman juga akan menyerap juga unsur tersebut.

Tingkat serapan logam berat oleh tanaman, selain ditentukan oleh besarnya jumlah kandungan logam berat dalam tanah, juga ditentukan oleh tingkat kelarutan logam tersebut dalam tanah. Salah satu sifat kimia tanah yang mempengaruhi tingkat kelarutan logam berat adalah reaksi tanah (pH tanah). Dari analisis korelasi tersebut menunjukkan bahwa $\mathrm{Cd}$ tanah berkorelasi negatif dan sangat signifikan dengan $\mathrm{pH}$ tanah, yakni semakin rendah $\mathrm{pH}$ tanah semakin tinggi tingkat kelarutan atau ketersediaan Cd dalam tanah.. Selanjutnya semakin tinggi ketersediaan $\mathrm{Cd}$ dalam tanah maka serapan $\mathrm{Cd}$ oleh tanaman juga semakin tinggi. Hubungan ini nampak jelas digambarkan dari ketiga Gambar di atas. Hasil yang sama juga diperoleh dari penelitian Dia dan Singh (1994), Miller et al. (1976) dalam U.S. Department of Energy Office of Environmental
Management (1998) bahwa dalam berbagai studi serapan $\mathrm{Cd}$ oleh tanaman akan menurun dengan peningkatan $\mathrm{pH}$ tanah. Secara umum hasil penelitian Chuan et al. (1996) menunjukkan bahwa logam akan sedikit (kurang) larut pada suasana basa $(\mathrm{pH}=8.0)$. Kelarutan logam lebih tinggi ketika dalam suasana sedikit asam $(\mathrm{pH}=5.0)$, dan meningkat secara drastis pada kisaran $\mathrm{pH} 3.3$.

Kadmium terdapat hampir selalu dalam bentuk divalen dan secara kimia mendekati sifat $\mathrm{Zn}$. Hasil penelitian Chaudri et al. (2001), menunjukkan adanya hubungan yang nyata dan bersifat linier antara $\mathrm{Cd}$ terlarut dengan $\mathrm{Cd}$ total dalam tanah, demikian pula antara $\mathrm{Cd}$ total dalam tanah dengan $\mathrm{Cd}$ yang terserap oleh tanaman. Namun demikian hubungan antara $\mathrm{Cd}$ terlarut jauh lebih linier dengan $\mathrm{Cd}$ dalam tanaman dibandingkan dengan $\mathrm{Cd}$ total dalam tanah.

Seperti yang telah diuraikan, bahwa terdapatnya $\mathrm{Cd}$ di lahan budidaya pada bantaran sungai salah satunya disebabkan oleh penggunaan air sungai untuk irigasi (penyiraman). Sementara penggunaan air sungai pada musim kemarau tentunya frekuensinya lebih tinggi dibanding pada musim penghujan, dan pada saat yang sama konsentrasi Cd dalam air sungai cukup tinggi. Oleh karena itu perpindahan $\mathrm{Cd}$ dari badan air sungai ke lahan budidaya (di bantaran sungai) akan semakin banyak jumlahnya bila semakin sering lahan tersebut digunakan untuk budidaya. 


\section{KESIMPULAN DAN SARAN}

\section{Kesimpulan}

Kandungan Cd dalam tanah di lahan bantaran sungai salah satunya akibat aktivitas manusia (anthropogenic). Hal ini terkait dengan penggunaan lahan untuk pertanian, dimana semakin lama penggunaan lahan untuk pertanian yang dibarengi dengan penggunaan air untuk penyiraman tanaman, maka semakin tinggi kandungan Cd dalam tanah. Penggunaan air sungai lebih banyak dilakukan pada saat musim kemarau, yaitu pada saat debit sungai rendah dan konsentrasi logam $\mathrm{Cd}$ dalam air sungai relatif tinggi, sehingga $\mathrm{Cd}$ yang terbawa oleh air ke dalam tanah juga semakin tinggi.

Ketersediaan Cd dalam tanah berkorelasi negatif dengan $\mathrm{pH}$ tanah dan semakin tinggi ketersediaan dalam tanah maka semakin tinggi tingkat serapan oleh tanaman. Kandungan $\mathrm{Cd}$ dalam jaringan akar jauh lebih tinggi dibandingkan kandungannya dalam tajuk tanaman (batang dan daun). Rata-rata kandungan kadmium dalam jaringan ketiga jenis tanaman di bantaran Sungai CBL menunjukkan nilai masih berada dibawah ambang batas maksimum yang diperkenankan.

\section{Saran}

1. Pemerintah perlu melakukan pengawasan yang lebih ketat terhadap industri yang membuang limbahnya ke Sungai Cikarang, Sungai Bekasi dan Sungai CBL, karena konsentrasinya dalam air sungai CBL sebagian telah melampaui batas Baku Mutu air Kelas IV.

2. Pada musim kemarau, petani yang bertanam sayuran di bantaran sungai sebaiknya tidak menggunakan air sungai untuk menyiram tanaman budidayanya, karena pada musim kemarau konsentrasi polutan sangat tinggi

\section{DAFTAR PUSTAKA}

Balai Penelitian Tanah. 2005. Petunjuk Teknis Analisis Kimia Tanah, Tanaman Air dan Pupuk. Badan Penelitian dan Pengembangan Pertanian Departemen Pertanian.

Chaudri, A. M., M. G. Allain, S. H. Badawy, M. L. Adams, S. P. McGrath, dan B. J. Chambers. 2001. Cadmium content of wheat grain from a long term field experiment with sewage sludge. J. Environ. Qual., 30:1575-1580.
Chuan, M. C., G.Y. Shu and J. C. Liu. 1996. Solubility of heavy metals in a contaminated soil: Effects of redox potential and $\mathrm{pH}$. Water, Air, \& Soil Pollution, 90: 543-556.

Darmono. 1995. Logam dalam Sistem Biologi Makhluk Hidup. UI Press. Jakarta.

Fachrul, M. F., H. Haeruman, dan L. C. Sitepu. 2004. Komunitas Fitoplankton Sebagai Bio-Indikator Kualitas Perairan Teluk Jakarta. Seminar Nasional MIPA 2005 FMIPA - Universitas Indonesia Depok, 24-26 November 2005.

Gundersen, P. and E. Steinnes. 2001. Influence of temporal variations in river discharge, $\mathrm{pH}$, alkalinity and $\mathrm{Ca}$ on the speciation and concentration of heavy metals in some mining polluted rivers. Aquatic Geochemistry, 7: 173-193.

Murray, K. S., D. T. Rogers, dan M. M. Kaufman. 2004. Heavy metals in an urban watershed in southeastern Michigan. Published in J. Environ. Qual., 33:163172.

Robert. 1999. Chemicals. The Environmental Council. http://www.wasteonline.org.uk/resources/Wasteguid e/ mn wastetypes_chemicals.html.

Salviano, A. M., R. L. F. Fontes, P. C. R. Fontes, dan J. C. L. Neves. 2001. Plant growth and cadmium distribution in plants of Brazilian tobacco cultivars as affected by cadmium in nutrient solution. Plant nutrition - Food security and sustainability of agroecosystems. W. J. Horst et al. (Eds.), Kluwer Academic Publishers. Printed in the Netherlands

U.S. Department of Energy Office of Environmental Management. 1998. Empirical Models for the Uptake of Inorganic Chemicals from Soil by Plants. Bechtel jacobs Company LLC. United State.

Vlamis, J., D. E. Williams, J. E. Corey, A. L. Page, dan T. J. Ganje. 1985. Zinc and Cadmium Uptake by Barley in Field Plots fertilizers seven years with urban and sub-urban sludge. Soil Sci. J., 139 : 8187.

World Health Organization (WHO). 1992. International Programme on Chemical Safety. Environmental Health Criteria 134. Cadmium. Geneva. http://www.inchem.org/documents/ehc/ehc/ehc134.h $\underline{\mathrm{tm}}$, 